\title{
The Effect of Collaborative Learning Aided by Mind Mapping Method on Science Learning Achievement
}

\author{
$1^{\text {st } I}$ Gede Margunayasa ${ }^{1}, 2^{\text {nd }} \mathrm{Ni}$ Nyoman Kusmariyatni ${ }^{2}, 3^{\text {rd }} \mathrm{Ni}$ Luh Sri Surya Wisma Jayanti ${ }^{3}$, \\ $4^{\text {th }}$ Ni Made Daini Vitra Sinta Sari ${ }^{4}, 5^{\text {th }}$ I Made Hendra Sukmayasa ${ }^{5}$ \\ \{pakgun_pgsd@yahoo.com\} \\ Jurusan PGSD, Universitas Pendidikan Ganesha ${ }^{12345}$
}

\begin{abstract}
This study aimed at analyzing the effect of collaborative learning aided by mind mapping method in lesson study setting after controlling achievement motivation on science learning achievement. This study was a quasi-experiment. The study was done with the fifth grade students in Cluster III and Cluster VII at Sawan District. The sample was selected using multi stage random sampling for three treatment groups. The first experimental group used collaborative learning $(n=57)$, the second experimental group used collaborative learning based on mind mapping $(n=52)$, and the control group used conventional teaching model $(\mathrm{n}=57)$. The study used science learning achievement test $(\mathrm{r}=0.77)$ and achievement motivation questionnaire $(\mathrm{r}=0.88)$ as the instruments for collecting the data. The hypothesis was tested using one-way ANACOVA. The result of hypothesis testing showed that, there was the effect of collaborative learning aided by mind mapping method in lesson study setting after controlling achievement motivation on the fifth grade students' science learning of the elementary schools in Cluster III and Cluster VII at Sawan District $(\mathrm{F}=65.6$ and $\mathrm{p}<0.05)$.
\end{abstract}

Keywords: Collaborative learning, mind mapping, lesson study, achievement motivation, science learning achievement.

\section{Introduction}

Contemporary teaching is oriented to acquiring the 21 st century skills known as "The $4 \mathrm{Cs}$ - communication, collaboration, critical thinking and creativity. The studies done so far have largely focused on the acquiring students' critical thinking and creativity, while the other two aspects, communication and collaboration, have not yet been studied enough. The result of observation at the elementary schools at Cluster III and Cluster VII in Sawan District showed that there is an important thing that has not been done yet by the teachers in relation to the $21 \mathrm{st}$ century skills, i.e., the teachers have not facilitated collaboration [1]. To address this the teacher should implement collaborative learning.

Collaborative learning is one the methods of learning that is focused on students that refers to interactional theory [2]. Learning is a process for building meanings through social interaction. Collaborative learning model is expected to improve student's participation, social interaction, and creativity at the time of learning. Collaborative learning is a group learning process in which every member contributes some information, experience, ideas, attitude, opinion, ability and skill that he or she has to improve the members' understandings [3]. The teaching through collaborative learning model is done by forming small heterogeneous groups. In each group the students interact and work together to solve a problem given by the 
teacher. Through the interaction and collaboration student-active learning will be developed. The effectiveness of collaborative learning depends on jumping tasks prepared by the teacher [2]. Before being given jumping tasks the students are given sharing tasks first as a guide to build knowledge by themselves according to the topic given.

Collaborative learning with sharing tasks and jumping tasks is not only beneficial to the students with a high academic level, but is also beneficial to the students with a low high achievement level [2]. Some study results showed the effectiveness of collaborative learning in improving students' learning achievement [2], [4], [5]. To be able to implement collaborative learning model more optimally, an aid from instructional media in the form of mind mapping method is provided. The results of studies showed that mind mapping method has an effect on students' science learning achievement [6], [7].

The optimizing collaborative learning implementation aided by mind mapping method can be done through lesson study. Lesson study is known in Japan as a method to analyze a case of teaching process, aimed at helping teacher professional development and opening opportunity for the teachers to learn from each other based on real practices in the classroom [8]. Lesson study is a collective work of a group of teachers and can include students and lecturers. Generally, the lesson study implementation is divided into 3 activities, that is, planning, implementation, and reflection. The writing of a lesson plan can be done collaboratively at the planning stage, implemented by appointing of the members as the model teacher, the other teachers play the role as observers, and then at the reflection stage, a process analysis is carried out together.

In addition to being caused by the method used by the teacher in teaching, learning achievement is also caused by achievement motivation [9], [10]. The achievement motivation is a psychological construct related to the effort to do something well on the basis of a healthy competition and the individuals are responsible to achieve a maximal result based on the standard of excellence [11]. The result of study found that there is a positive correlation between achievement motivation and student's academic achievement [12]. The achievement motivation as defined in this study is the student's inherent factor before the lesson starts, not as the effect of the implementation collaborative learning. To measure this, the achievement motivation was measured before the study started. This study tried to find the effect collaborative learning aided by mind mapping method in lesson study setting on science learning achievement by controlling achievement motivation. The primary hypotheses was that there is a significant difference in science learning achievement between the students who learned through collaborative learning model in lesson study setting and that of those who learned through conventional teaching after controlling achievement motivation.

\section{Methods}

The datasets of this study is accesable at https://osf.io/pzjf3 [13]. This study was conducted using an experimental design. The population consisted of 233 students or all of the fifth grade students of elementary schools in Cluster III and Cluster VII in Sawan District. The sampling was done using multi stage random sampling [14]. At the first stage $50 \%$ of classes of each cluster so that 4 classes from the elementary schools in Cluster III and 2 classes from elementary schools in Cluster VII were selected randomly. At the second stage, from the 6 classes selected at the first stage a class that would implement collaborative learning using lesson study setting as E1 $(n=57)$ was randomly selected again to determine a class that would 
implement collaborative learning aided by mind mapping method in lesson study setting as E2 $(n=52)$, and conventional learning as $K(n=51)$.

In this study, the instruments used were science learning achievement test in a multiple choice format $(\mathrm{r}=0.77)$ and achievement motivation questionnaire $(\mathrm{r}=0.88)$. The test of science learning achievement consists of 30 items, every correct answer is given 1 score and a wrong answer is given 0 . The score of each correct answer is then added up and the total number is the score obtained for science learning achievement. The science learning test was developed by the researchers based on learning indicators that formed an integration between cognitive domain in the revised Bloom's taxonomy that consists of remembering ( $\mathrm{C} 1)$, comprehension (C2), application (C3), analysis (C4) and evaluation (C5). Achievement motivation questionnaire has 5 aspects: (1) the presence of effort to achieve success, (2) success orientation, (3) being innovative, (4) being responsible, (5) anticipation of failure [11]. The hypothesis was tested using one-way ANACOVA.

\section{Result and Discussion}

The result of data descriptive analysis on science learning achievement is as shown in Table 2. Based on table 2, it is known that the mean of the students' learning achievement of those who learned through collaborative learning in lesson study setting was lower than that of those who learned through collaborative learning aided by mind mapping method in lesson study setting and higher than that of those who learned through conventional teaching. The highest mean in science learning was obtained by the students who learned through collaborative learning aided by mind mapping method in lesson study setting.

Table 2. Descriptive analysis of data on science learning achievement

\begin{tabular}{lllc}
\hline Group & $\mathrm{N}$ & Mean & Standard Deviation \\
\hline E1 & 57 & 22.14 & 3.98 \\
E2 & 52 & 23.60 & 3.96 \\
K & 51 & 16.12 & 3.97 \\
\hline
\end{tabular}

Before hypothesis testing was done, a prerequisite testing was done which consisted of data normality testing, homogeneity testing, and linearity testing. The data normality testing was done by using Kolmogorov-Smirnov test which yielded sig. $>0.05$, meaning that the data on science learning achievement had a normal distribution. The variance homogeneity test was done using Levene's test and yielded $\mathrm{F}=0.75$ and sig $>0.05$, meaning that science learning achievement of each group was homogeneous. The linearity test yielded $F=41.11$ and sig of deviation from linearity $<0.05$, meaning that the relation between achievement motivation and science learning achievement was linear.

The hypothesis testing was done by using one-way ANACOVA. The result showed the F value $=107.88$ and sig. $<0.05$. This means that the $F$ value obtained was significant. This means that there is a significant difference in science learning achievement between the students who learned through collaborative learning model in lesson study setting and that of those who learned through conventional teaching after controlling achievement motivation among the fifth grade students of elementary schools in Cluster III and Cluster VII in Sawan District, Buleleng Regency in the school year 2017/2018. Hence, collaborative learning model aided by mind mapping method in lesson study setting had an effect on science learning 
achievement after controlling students' achievement motivation in the fifth grade students in elementary schools in Cluster III and Cluster VII in Sawan District in the school year 2017/2018.

Based on the result of that analysis we can ask a question why collaborative learning aided by mind mapping method in lesson study setting is the most effective in producing science learning achievement score? The answer to this question is as follows. Collaborative learning model has five main stages, every stage that is taken gives a positive change in the student and teacher. The first stage is student orientation. At this stage the teacher guides the students to dig the knowledge that they have by giving interesting things in apperception, for example, in the topic of light refraction the teachers provided apperception by bringing in a round shaped aquarium with a goldfish inside. The students were enthusiastic to see the aquarium and this opportunity was used by the teachers to ask some questions, such as "what does the fish look like from the place you sit?" and "why does the fish look bigger if seen from the place where you sit? The question directed the students to the lesson implemented so that the students were able to focus their attention on learning activities. The lesson that started with a focused mind and self-confidence can make the feeling of fright and negative thinking during the learning activities disappear [15].

At the second stage, the students form a group. At this stage the teachers guided the students to form a small heterogeneous group that consists of at the most 4 students. The finding at this stage is that the students initially worked at a less than maximum rate changed into a maximum rate and communicated with one another more interactively. The setting of their seats was in a group setting that formed a "U" shape. The mixing of boys and girls in the process of group formation makes the students more active in the exploration process since the communication that occurs was more interactive [16]. The " $U$ " shape like seating arrangement makes the learning more conducive since information communicated can be heard well by the students and the teacher. In addition, the students feels a joy since there is no student sitting at the the farthest back or the farthest front. All students' activities can be seen clearly, and every student can see his or her friends seriously attending the lesson and the student feels challenged to be serious too in attending the lesson and listening to the teacher's explanation The "U" shape like seating arrangement makes it easy for the teacher to guide the students. The time efficiency is also the advantage of collaborative learning since at the time of group formation the students need only to turn their bodies to make the class atmosphere more conducive. The group of 4 students is more effective since all the members will work and have partners to communicate with.

Third, the teacher guides the students at the stage of tasks writing. At this stage, student exploration activity occurs that the students do through an experiment. The finding of this study showed that the students were very enthusiastic in doing the experiment to find a concept, for example in the light refraction topic, a student tried to put a pencil into a transparant glass that was filled with water. It turned out that from the outside, the pencil looked curved, the fact was it was not curved. The students in the group started to take a note of the result of the finding on their worksheets. During the exploration process the students depended positively on each other through an effective, joyful, unmonotonous communication. Collaborative learning model has been proven to be more effective in inducting students' cognitive development since the learning situation is collaborative since there is positive dependence to achieve success [5].

Fourth, the teacher facilitates student collaboration at the time they do sharing tasks and jumping tasks. Sharing task is a problem at the textbook level and jumping task is a task at a higher level. The finding at this stage is that the students who did the sharing task tended to do 
it individually, while in doing the jumping task they did it collaboratively. The important thing in collaborative learning is to make the students focus on learning and this can be done by assigning sharing tasks and jumping tasks gradually [2]. Fifth, the evaluation stage and the evaluation of the tasks completed by the students. The finding of this study showed that the students who initially only depended on clever group members started to learn to be responsible for the task personally. Then, they were also responsible for communicating what they had done since the teacher also asked them by appointing anyone of them to present the result of his or her result. In the process of expressing opinions, the students previously had sought their friends' different opinions by using the system of appointing the teacher invited students with different opinions to express their opinions, so that from the differences a conclusion can be drawn.

In addition to collaborative learning stages, the use of mind mapping method was also very helpful for the students to achieve science learning achievement. The students became more motivated in learning since there was an activity of writing mind maps at the end of the lesson. This is supported that mind mapping method is more interesting and stimulating than the traditional technique of note taking [17]. In collaborative learning, mind mapping method is made at the end of learning after the students obtain information and then visualize it in an attractive mind map. This activity makes knowledge acquired through collaborative learning become more structured and organized so that the students' retention will last longer. This is in line with other researchers that stated that making a mind map is one of the ways to assimilate the concepts that the students have learned [18]. Different from the teaching that was done in the control group who learned through conventional teaching, the students tended to be passive in an in-depth study of something. The teaching implemented still focused on the teacher. The teacher dominated the teaching process by explaining the material, doing a question and answer activity with the students and then assigning tasks to the students to give scores to the latter. This makes the students just listen and take a note of what the teacher communicates without trying to find by themselves concepts that they learned.

\section{Conclusion}

Mind mapping method aided collaborative learning follows the stages: (1) student orientation, (2) formation of collaborative groups, (3) learning tasks writing, (4) facilitating student collaboration through sharing tasks and jumping tasks, making mind maps, and (5) evaluation of collaborative learning model aided by mind mapping method implemented in lesson study setting. Collaborative learning model aided by mind mapping method in lesson study setting is very effective in improving science learning achievement. The suggestions made to improve science learning achievement, among other things, are that for the teachers it is expected that they try to continue using collaborative learning model aided by mind mapping method in lesson study setting in science or other subjects, to assign sharing tasks and jumping tasks to the students that are adjusted to the level beyond that of the book or a higher level. In addition, the teachers are also expected to facilitate student collaboration optimally by connecting the students who ask questions with the students who understand the material, and the teacher should pay more attention to the students with a low academic ability. The head of the school should conduct training activities on collaborative learning model aided by mind mapping method in order other teachers can implement it. The training should use lesson study design. 


\section{References}

[1] I. G. Margunayasa, Hasil observasi. Singaraja: Tidak diterbitkan, 2018.

[2] Marhamah, Mustafa, and Melvina, "Pengaruh Model Pembelajaran Kolaboratif Berbasis Lesson Study Learning Community (LSLC)," J. Ilm. Mhs. Pendidik. Fis., vol. 2, no. 3, pp. 277-282, 2017.

[3] R. Andriani, Zulhelmi, and Azizahwati, "Differences of Student Attitude in Collaboration based on Gender in Physics by Using Collaborative Learning Model in 10th Grade Madrasah Aliyah AL Ihsan Boarding School Kampar," J. Online Mhs. Fak. Kegur. dan Ilmu Pendidik. Univ. Riau, vol. 2, no. 2, pp. 1-15, 2015.

[4] S. Santoso, "Pengaruh Model Pembelajaran Kolaboratif dan Motivasi Belajar Terhadap Peningkatan Hasil Belajar Fisika Siswa Kelas X SMA Negeri 1 Purwantoro Wonogiri Jawa Tengah," Berk. Fis. Indones., vol. 5, no. 1, pp. 15-19, 2013.

[5] Primadiati Ika Dewi and Djukri, "Pengaruh Model Collaborative Learning terhadap Peningkatan Motivasi dan Hasil Belajar IPA Siswa Kelas IV SD," J. Prima Edukasia, vol. 5, no. 1, pp. 47-57, 2017.

[6] N. M. D. Kartika and I. G. Margunayasa, "Pengaruh Model Pembelajaran Inkuiri Terbimbing Berbantuan Peta Pikiran Dan Motivasi Berprestasi Terhadap Hasil Belajar IPA," Mimb. PGSD, vol. 5, no. 2, 2017.

[7] R. S. Lumentut, I. Said, and Kasmudin Mustapa, "Pengaruh Model Pembelajaran Guided Inquiry Dengan Mind Map Terhadap Hasil Belajar Dan Motivasi Siswa Pada Materi Redoks Di Kelas X SMA Negeri 5 Palu," J. Akad. Kim., vol. 6, no. 2, pp. 113-118, 2017.

[8] Rusman, Model-Model Pembelajaran Mengembangkan Profesionalisme Guru. Bandung: Raja Grafindo Persada, 2010.

[9] H. Djaali, Psikologi Pendidikan. Jakarta: PT. Bumi Aksara, 2008.

[10] M. Dimyanti;, Belajar dan Pembelajaran. Jakarta: Rineka Cipta, 2006.

[11] N. K. Suarni, Meningkatkan Motivasi Berprestasi Siswa Sekolah Mengah Umum di Bali dengan Strategi Pengelolaan Diri Model Yates. Yogyakarta: Universitas Gadjah Mada., 2004.

[12] A.-O. Emmanuel, E. A. Adom, and B. Josephine, "Achievement Motivation, Academic Self-Concept And Academic Achievement Among High School Students," Eur. J. Res. Reflect. Educ. Sci., vol. 2, no. 2, 2014.

[13] I. G. Margunayasa, "Datasets The Effect of Collaborative Learning Aided by Mind Mapping in the Lesson Study Setting on Science Learning Achievement," 2019. [Online]. Available: https://osf.io/pzjf3/.

[14] N. Dantes, Metode Penelitian. Yogyakarta: Andi, 2012.

[15] B. Deporter, Quantum Learning, Membiasakan Belajar Nyaman dan Menyenangkan. Bandung: Kaifa, 2012.

[16] M. Sato, Mereformasi Sekolah Konsep dan Praktek Komunitas Belajar. Tokyo: Iwanami Shoten Publishers, 2014.

[17] T. Buzan, Buku Pintar Mind Map untuk Anak. Jakarta: PT Gramedia Pustaka Utama, 2007.

[18] N. K. T. Y. Wardani, N. M. Sulastri, and I. G. Margunayasa, "Pengaruh Model Heuristik Vee dengan Peta Pikiran terhadap Hasil Belajar IPA Siswa Kelas V SD," Mimb. PGSD, vol. 3, no. 1, 2015. 